Article

\title{
An Application of the A'WOT Analysis for the Management of Cultural Heritage Assets: The Case of the Historical Farmhouses in the Aglié Castle (Turin)
}

\author{
Marta Bottero ${ }^{1}{ }^{\mathbb{D}}$, Chiara D’Alpaos ${ }^{2, *}$ and Alessia Marello ${ }^{1}$ \\ 1 Department of Regional and Urban Studies and Planning, Politecnico di Torino, 10129 Torino, Italy; \\ marta.bottero@polito.it (M.B.); alessia.marello@hotmail.it (A.M.) \\ 2 Department of Civil, Environmental and Architectural Engineering, University of Padova, \\ 35122 Padova, Italy \\ * Correspondence: chiara.dalpaos@unipd.it
}

Received: 20 December 2019; Accepted: 24 January 2020; Published: 3 February 2020

check for updates

\begin{abstract}
In recent years, governments, public institutions, and local communities have devoted growing attention to the identification of promising strategies for the preservation and valorization of cultural heritage assets. Decisions on the management of cultural heritage assets based on multiple, often conflicting, criteria and on the stakes of various, and potentially non-consensual actors and stakeholders. In this context, in which the trade-offs between the preservation of assets historical symbolic values and the adaptation to alternative and economically profitable uses play a key role in investment decisions, multi-criteria analyses provide robust theoretical and methodological frameworks to support decision-makers in the design and implementation of adaptive reuse strategies for cultural heritage and public real estate assets. In this paper, we provide a multi-criteria decision aiding approach for ranking valorization strategies of cultural heritage assets aimed at promoting their restoration and conservation, as well as at creating cultural and economic benefits. In detail, we present a novel application of the A'WOT analysis to support the design and implementation of alternative management strategies of abandoned cultural heritage assets. The paper focuses on the potential reuse and management of four historical farmhouses (Cascina Mandria, Cascina Lavanderia, Cascina Gozzani, and Cascina Ortovalle) located in the Agliè Castle estate, one of the Residences of the Royal House of Savoy, currently listed in the UNESCO World Heritage Sites.
\end{abstract}

Keywords: cultural heritage; A'WOT analysis; multicriteria decision aid; valorization; management strategy

\section{Introduction}

The problems in the context of cultural heritage conservation and valorization refer to multi-faceted issues described by several dimensions, such as historic and artistic values, economic constraints, technical aspects, and a plurality of actors and stakeholders who play important roles in the decisional arena. Such as public authorities, practitioners, tourists, inhabitants, and so on. Of particular importance in this domain is the concept of adaptive reuse, which involves a change of use of existing buildings with the aim to achieve improvement in environmental, economic and social dimensions of sustainability, including resource efficiency, costs reduction and intrinsic values retention [1-6]. In the light of this complexity, decision-making processes in the domain of cultural heritage operations need to be addressed by specific evaluation tools, able to consider both the use-values related to the tangible benefits provided by Cultural Heritage to people and non-use values, accruing to current potential and future users, under the perspective of the Social Complex Value $[7,8]$.

In particular, the evaluation of cultural heritage focused so far on two main directions: 
- non-market valuation by means of Stated/Revealed Preferences methods,

- Multicriteria evaluation methods and decision-making approaches.

As far as the first group of methods are concerned, they have been primarily introduced by economists to value public goods, which are non-excludable and non-rivaled in consumption [9]. Cultural heritage typically possesses the characteristics of public goods and thus can be valued by implementing non-market valuation methods. Broadly speaking, there are two categories of non-market valuation methods: Stated Preferences methods, such as Contingent Valuation Method or Choice Experiments, which estimate the value individuals place on public goods by means of direct elicitation queries in terms of Willingness To Pay [10], and Revealed Preferences methods, such as Travel Cost Method or Hedonic Models, which infer values from individual choices within real markets [11]. With reference to the context under investigation, it has to be noticed that heritage economics established as an area of analysis for the valuation of benefits provided by cultural heritage projects and different applications exist with reference both to Stated Preference and Revealed Preferences Methods [12-15].

Regarding multicriteria evaluation, these methods are used to make a comparative assessment of alternative projects or heterogeneous measures and they allow several criteria to be taken into account simultaneously, considering the opinions of the different stakeholders involved in the decision-making process [16]. In the context of cultural heritage, multi-criteria approaches proved to be able to provide a systematic vision of project effects, taking into account both the qualitative and the quantitative aspects of the decision problem [17-20].

The objective of the paper is to explore the use of a novel hybrid multi-criteria method named $\mathrm{A}^{\prime}$ WOT for supporting a real-world problem in the context of cultural heritage. In particular, the method combines two common approaches used in decision analysis, namely the Analytic Hierarchy Process (AHP) [21], and Strengths, Weaknesses, Opportunities and Threats (SWOT) Analysis. SWOT analysis bases on internal and external valuation criteria to identify strengths and opportunities, which can positively encourage the achieving of objectives, as well as weaknesses and threats, which can adversely affect achieving the objectives. Its contribution to the development of sustainable valorization strategies addressing abandoned cultural heritage is to maintain the strengths, find solutions for weaknesses, capitalize on opportunities and prevent threats. As it might become onerous to come to concordant decisions by solely implementing a SWOT analysis, due to the qualitative nature of its value judgments, the AHP is used to derive priorities and relative importance of criteria, sub-criteria and alternatives in a formal, analytical way, based on experts' judgment.

In the present paper, an $A^{\prime}$ WOT model has been developed with the purpose of addressing the design and management of the historic farmhouses in the Aglié Castle in Northern Italy. In our framework, SWOT analysis captures potential drivers (i.e., opportunities and strengths) and barriers (i.e., threats and weaknesses) to promote an in-depth understanding of the framework conditions of the ducal farmhouses system, whereas AHP is used to define the priorities of the elements under examination. Thanks to this understanding, we drew new sustainable strategies for the valorization of these assets and we prioritized ducal farmhouses according to their potential in successful strategy implementation.

The rest of the paper is organized as follows. Section 2 presents the methodological background and focuses on the A'WOT method. Section 3 presents the A'WOT model provided to identify top-priority targets among the farmhouses of the Aglié Castle. It describes the structuring of the decision problem thought the SWOT matrix and the evaluation procedure implemented to identify priorities of SWOT categories and factors and the final ranking of alternatives. Section 4 illustrates and discusses the results. Finally, Section 5 synthetizes conclusions and provides guidelines for the design of interventions and the identification of successful management strategies.

\section{Methodological Framework}

Strategic management of cultural heritage assets and their valorization involve the analysis of both interactions between these assets and the environment that surrounds them and internal and 
external factors, which affect the successful implementation of sustainable interventions to restore and enhance them.

In this respect, the Strengths, Weaknesses, Opportunities, and Threats (SWOT) analysis is a systematic approach to assess internal and external factors $[22,23]$ as well as potentials and pitfalls, which guarantees a fact-based, data-driven insight on planning decisions and course of actions, thus providing a good basis for strategy definition [24,25]. The SWOT analysis was firstly developed for business and market analysis and it is currently extensively implemented in planning and management and adopted in many fields for research assistance in order to evaluate potential bottlenecks or opportunities to prioritize development and/or management strategies [26,27]. Strengths may enhance overall performances and provide an advantage, whereas Weaknesses may affect efficiency, profitability and competitive advantage. Opportunities are possibilities, which may contribute to exploit advantage or add additional advantage, whereas threats may generate problems and retrieve successful development and implementation of any strategy.

Nonetheless, SWOT analysis can mainly support in the accurate identification of key factors in the analysis, but it does not provide any analytical tool or algorithm to determine the relative importance of these factors in the decision-making process, as results are provided in terms of qualitative assessment $[25,28,29]$. To address this issue and to improve the quantitative information basis of strategic planning processes, Reference [28,29] proposed the A'WOT method, a hybrid tool, which combines the SWOT analysis and the Analytic Hierarchy Process (AHP), proposed by Saaty in the Eighties [21]. The AHP is a well-established technique to address complex decisions and obtain a priority ranking of alternatives. Criteria, sub-criteria, and alternatives relative importance are determined through pairwise comparisons expressed in semantic judgments converted into numerical values according to Saaty's fundamental scale [21].

In the A'WOT model, the AHP is therefore used to evaluate the SWOT factors, as well as the four SWOT categories (i.e., Strengths, Weaknesses, Opportunities, and Threats) and make them commensurable with respect to their priority intensities.

The integration of AHP with SWOT analysis provides analytically determined priorities, according to the eigenvalue approach to pairwise comparisons, and allows comparing alternatives with respect to each SWOT factor and ranking them from best to worse with respect to the goal of the decision-making problem [30]. The $\mathrm{A}^{\prime}$ WOT decomposes a complex decision problem into a simple hierarchy. According to the AHP, at the top of the hierarchy, there is the goal, whereas SWOT categories (i.e., criteria) and SWOT factors (i.e., sub-criteria), which contribute to the goal are at lower levels and alternatives under investigation are at the bottom of the hierarchy.

According to [28], the $\mathrm{A}^{\prime} \mathrm{WOT}$ method is structured into the following subsequent phases:

1. SWOT analysis (identification of internal and external factors) and decomposition into hierarchical levels,

2. Pairwise comparisons of factors and SWOT categories,

3. Final ranking.

Firstly, the SWOT analysis is carried out, and internal and external factors are identified. Secondly, pairwise comparisons of factors (with respect to each SWOT category) and of SWOT categories (with respect to the goal) are performed and priorities (i.e., preference intensities) are calculated. At this stage, weights (i.e., priorities) are determined according to the eigenvalue approach to pairwise comparisons and pairwise comparisons of elements at each level are conducted with respect to their relative importance towards their parent node [31]. The consistency of pairwise comparison matrices is then verified by determining the inconsistency index IC, which is usually considered as acceptable whenever IC $<0.10$ [21]. Finally, we obtained the priority ranking of alternatives via a weighted sum aggregation procedure, from the bottom to the top of hierarchical levels.

Starting from the seminal works by [28,29], a significant strand of literature developed and the number of its applications to real-world decision problems increased significantly [32-34]. 
The applications of the A'WOT method are varied and cover as major fields natural resource management [32,35-37], sustainable tourism and tourism management [25,34,38,39], strategic assessment and group decision making (see among others, [40-43]). Although in the field of cultural heritage assessment, there are a flourishing set of recent contributions in literature on the sole application of AHP [44-51] and SWOT analysis [52-56], respectively. Nonetheless, to our knowledge, there are no contributions on the application of $\mathrm{A}^{\prime} \mathrm{WOT}$ to strategic decisions on cultural heritage. This contribution complements the existing literature on $\mathrm{A}^{\prime}$ WOT methods with a novel application in cultural heritage and provides a new investigation of strategic choice on the valorization of abandoned and severely damaged assets.

\section{Case Study}

\subsection{Description of the Case Study: The Ducal Farmhouses in Aglié Estate}

The township of Agliè is located in the Canavese area, about $40 \mathrm{~km}$ from Turin. It has a varied territory and it is located partly in the hilly area of the Ivrea morainic amphitheater and partly in the plain to the south. The agricultural area features arable land, meadows and poplar groves on the plain and vineyards, as well as wooded areas, on the hills. The ducal farmhouses, established to serve Agliè Castle, together with a system of reserves, farms, and estates, represent the assets in possession of the Savoy family [57]. Their main function was agricultural management.

In 1764 Benedetto Maria Maurizio, Duke of Chiablese, bought the estate of Agliè Castle and its park and other possessions, including the "Cascina del Parco" (Lavanderia), owned by the Marquis San Germano, Cascina Valle owned by the Count of Agliè and Cascina Gozzani, belonging to poet Guido Gozzano's family (Figures 1 and 2).

The farmhouses, joined in one property, were called "Cascine Ducali" [58]. In 1769, Count Ignazio Birago di Borgaro planned new expansions of the existing buildings as well as new settlements, including Cascina Allea.

Cascina Allea (called Mandria) was designed between 1772 and 1773, thanks to the drawings and instructions of Birago di Borgaro, at the service of the Duke of Chiablese [59]. This building is interesting mainly because of its location within the context of the Castle Park and the architecture of its façade. The complex is formed by a closed court organized around a quadrangular space. A U-shaped volume forms the structure and it has an axis of symmetry passing through the large entrance arch. The structure is composed of three main volumes. The structure does not appear to be in an advanced state of degradation but it is damaged by a lack of maintenance and by exposure to the action of atmospheric agents.

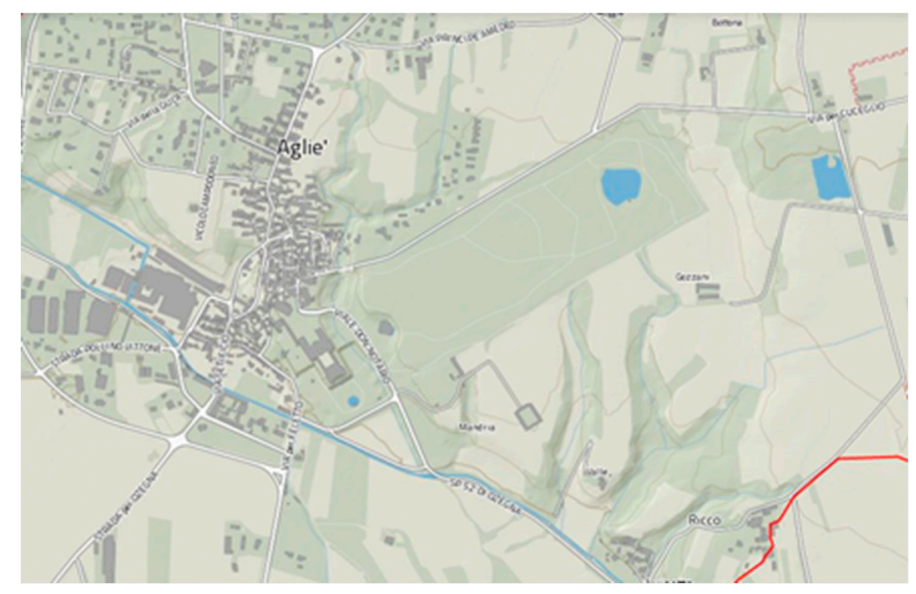

Figure 1. Cartography extrapolated from the geoportal representing the system of the Castle and ducal farmhouses, Municipality of Agliè, http://www.geoportale.piemonte.it/geocatalogorp. 


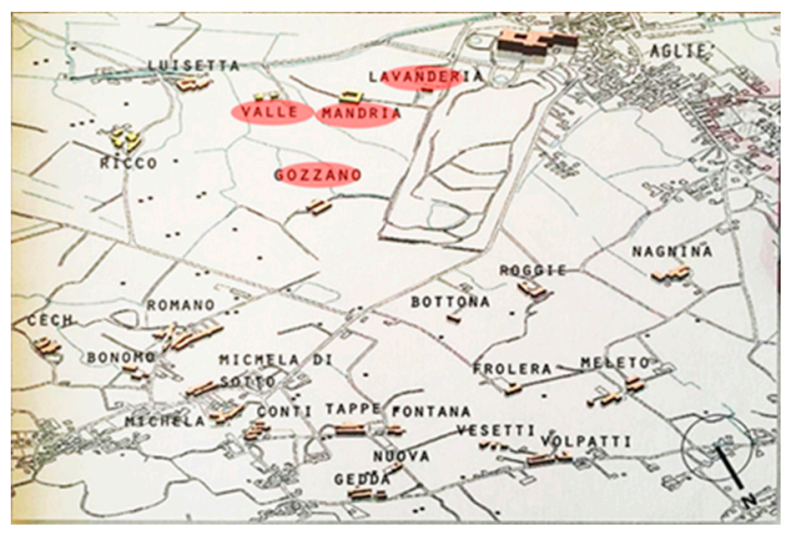

Figure 2. Cartography extrapolated from the Ancient Archive of Agliè Municipality ("Comune di Agliè").

Cascina Ortovalle has been represented on historical maps since 1745. It is a single building with simple wings and was mainly used for cultivations of fruit and vegetables. The structure is located on a hill and can be accessed by a poorly maintained dirt road. The building is in good condition since it is inhabited. It has a large terrace looking into the countryside of Agliè and a wall surrounds it. The context in which Cascina Ortovalle is located is characterized by large cultivated fields and the structure is well connected to the city through the main road. Presently the building can be used on all stories, it is not at risk of collapse and it does not present a compromised crack pattern. The architectural structure has a large barn with a trussed roof, which was restored a few months ago by the current tenants of the building.

Cascina Gozzani is composed of two buildings and is located south-east of Agliè, not far from the park. The historical cadastral maps attribute ownership of Cascina to Guido Gozzano's family. The complex is characterized by a planimetric layout composed of an internal courtyard with a double opposing row that is spread throughout the Canavese countryside. The two buildings face each other at close range and they are connected to each other through a surrounding wall. The position in which it is located is rather isolated because it is more to the north and far from the city center and the castle. The functional division between the two buildings reflects the theme in which they're inserted, on the northern side, there are the residential and service functions, including the rooms of the Lord, an area which stands out for its height and turns towards the east. The general situation of the complex is considerably compromised. A recent inspection revealed the definitive collapse of part of the roof, added to degradation phenomena of extended areas from the upper floors through the ground floor. The main reason related to this phenomenon is the total absence of maintenance by the State, which owns the property and has not tried to limit damages to both buildings. The main causes of deterioration of the structures concern substantial infiltrations of water through cracks and collapses of the roofs, which have caused considerable damage to the underlying areas.

Among the farmhouses, Cascina Lavanderia is the closest to the Park and, due to its location, on historical maps, it is referred to as "Cascina del Parco" [60]. Its role was of service to the Castle and it was destined for the cultivation of vegetables and food preservation. The farmhouse is situated in a strategic position with respect to the Park, in an area next to the south-west border and the main access road and numerous paths directly connect it to the Park. From an architectural point of view, the structure is a simple two-story wing, with a stairwell in its central part. The state of conservation of this building is almost totally compromised. The structure is secured thanks to a system of beams to help in stabilizing it and reducing the risk of collapse. The roof and ceiling are almost completely collapsed, thus damaging the horizontal surfaces of the lower floors, and some of these rooms host dense vegetation (Figure 3). 

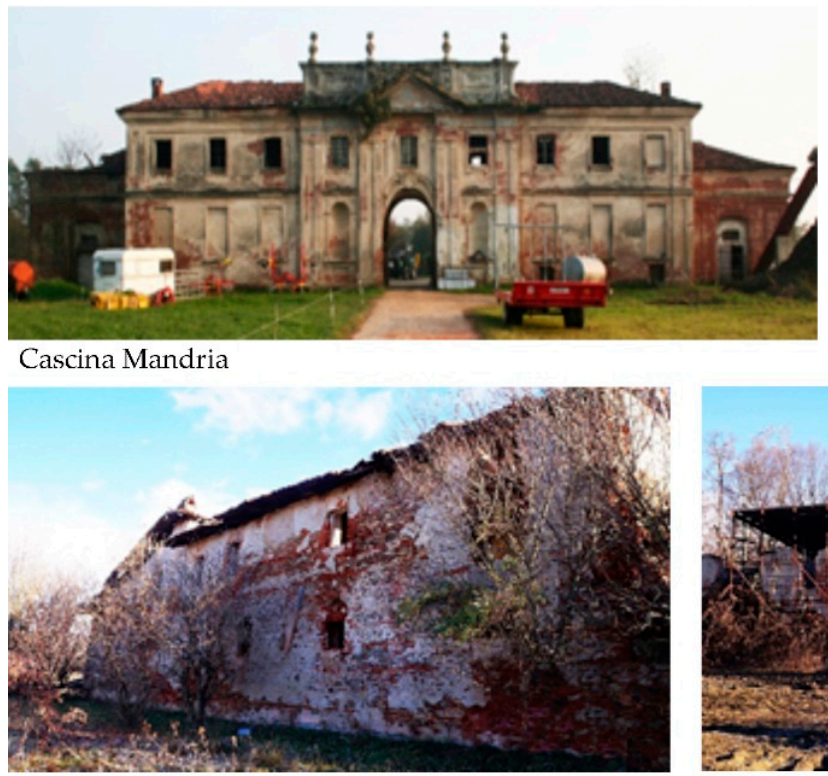

Cascina Gozzano

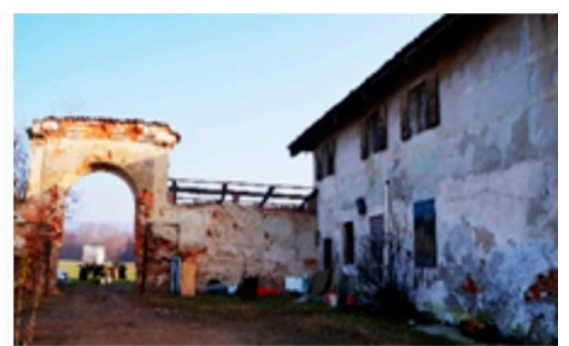

Cascina Ortovalle

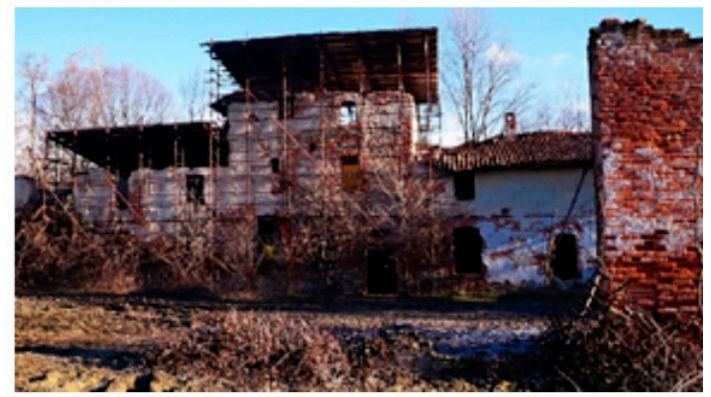

Cascina Lavanderia

Figure 3. The farmhouses of the Aglié Castel (photos by the authors).

\subsection{The A'WOT Model}

Starting from the analysis of the historic farmhouses of the Aglie Castle, in this paper we provide new management strategies of these assets aiming at their preservation and valorization. To this purpose, we developed an A'WOT model with the objective of ranking the four farmhouses according to their potential for successful valorization strategy implementation. They are ranked from best to worst in terms of priorities of potential successful intervention.

As described in Section 2, we structured the modeling into three main subsequent stages. The first step of the modeling consists of the implementation of the SWOT analysis and construction of the SWOT matrix in order to structure the decision problem. In particular, the SWOT categories (namely Strengths, Weaknesses, Opportunities and Threats) were further broken down into specific sub-criteria, which represent the key aspects in the evaluation of cultural heritage assets. To identify the above-mentioned SWOT factors, we conducted an extensive literature review on cultural heritage valorization and interviewed a panel of experts composed by an officer of the Superintendence of Turin and by three experts in the field of history of architecture, restoration, and structural analysis, and economic valuation, respectively.

The SWOT factors identified, grouped into to Strengths S, Weaknesses W, Opportunities O and Threats T, can be described as follows.

- $\quad$ S1 accessibility: it considers the mobility network for reaching the farmhouses,

- S2 state of conservation: it is related $t$ to the current level of maintenance of the buildings,

- S3 historical/cultural value: it considers the value of the building as resulting from specific documents and sources,

- W1 current use: it takes into account the current function of the asset or the abandoned condition,

- W2 ownership: it refers to the present ownership of the properties, whether of the Superintendence or of specific private entities,

- W3 operation and maintenance (O\&M) costs: they are related to building structure and materials, recreation, consumption and production activities host in the farmhouse,

- O1 flexibility: it takes into account the potential of transforming and restoring the building, whereas maintaining the readability of the original structures and functions,

- $\mathrm{O} 2$ quality of the context: it refers to the quality of the surrounding natural environment, 
- O3 network infrastructures: it takes into account whether the farmhouse is connected to public network infrastructures (e.g., utilities),

- $\quad$ T1 relationship with the context: it is related to the typology and state of maintenance of built environment surrounding the asset,

- T2 regulatory risks: it refers to changes in regulation which can affect the business or property use),

- T3 budget constraints: it refers to a credit crunch, lack of financial resources and potential investors.

According to the aforementioned structure, we then compiled four SWOT matrixes, one for each farmhouse under investigation. As an example, Appendix A reports the SWOT matrix that has been constructed for Cascina Lavanderia.

In the second phase, according to the AHP [21], the SWOT factors have been organized into a hierarchical structure (Figure 4), in which at the top of the hierarchy there is the goal (i.e., ranking of ducal farmhouse with respect to their potential in the implementation of successful, sustainable valorization strategies), at lower levels, there are criteria (i.e., SWOT categories) and sub-criteria (i.e., SWOT factors), respectively. At the bottom of the tree-like structure, there are the alternatives under investigation (i.e., the ducal farmhouses in the Aglié estate), to be compared in order to determine their relative importance and the final ranking.

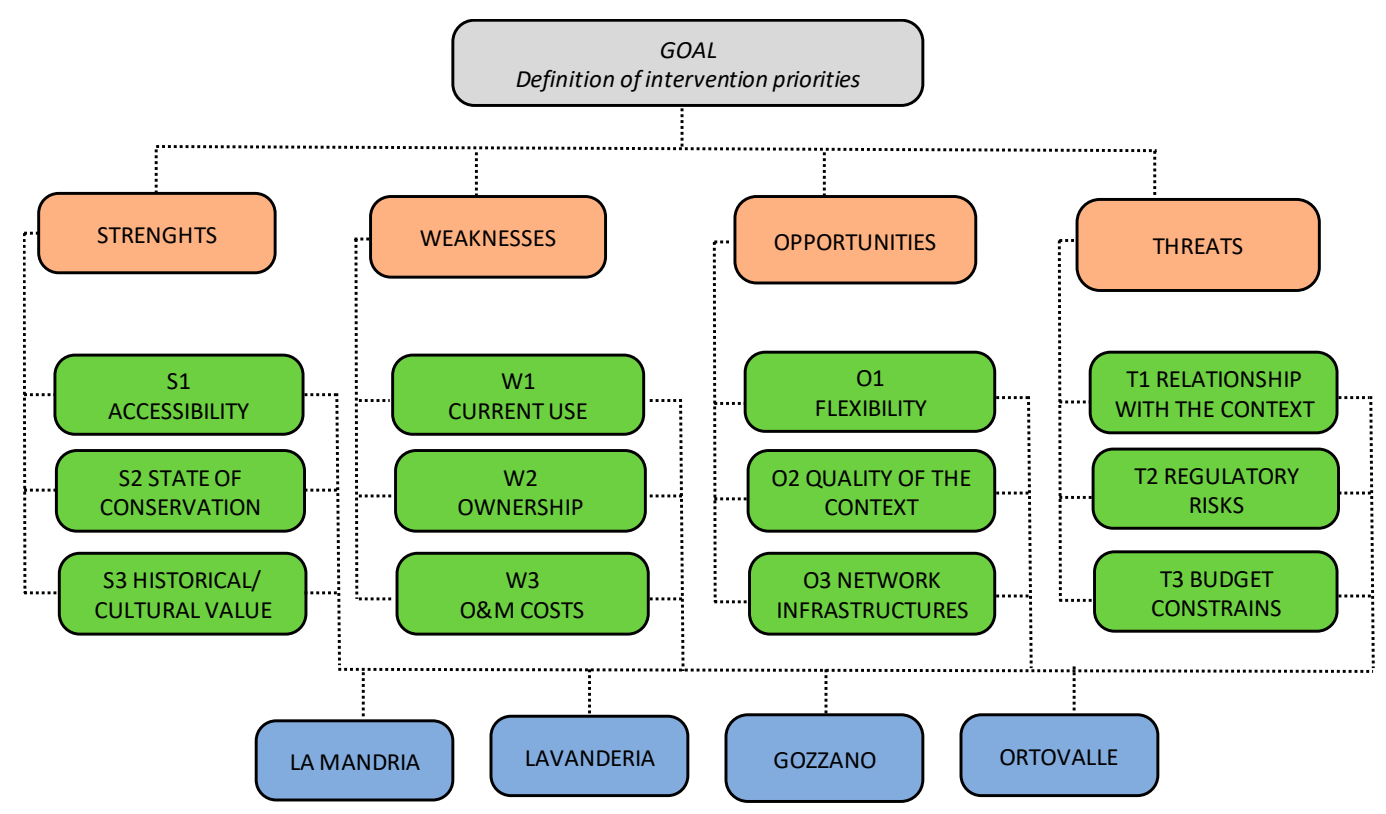

Figure 4. Structuring of the decision problem through the A'WOT (a hybrid tool, which combines the Strengths, Weaknesses, Opportunities, and Threats (SWOT) analysis and the Analytic Hierarchy Process (AHP) method.

As required by the AHP method, firstly it was necessary to evaluate the criteria level, i.e., the SWOT categories, and the sub-criteria level, i.e., the SWOT factors. To this purpose, being more strategic and general levels of the problem, we asked the officer of the Superintendence, involved in the panel of experts, to fill in the pairwise comparison questions related to the relative importance of SWOT categories and SWOT factors. Figures 5 and 6 report an example of questions for the evaluation of the SWOT categories and factors, respectively.

Once all the pairwise comparison questions were filled in, we calculated the priorities of SWOT categories and factors as resulting from the Superintendence officer's interview (see Section 4). 
With reference to the definition of the potential in asset valorization of the historical farmhouses in Aglie Caste, which of the two criteria do you think is more important? And to what extent?

\begin{tabular}{l|l|l|l|l|l|l|l|l|l|l|l|l|l|l|l|l|l|} 
Strengths & 9 & 8 & 7 & 6 & 5 & 4 & 3 & 2 & 1 & 2 & 3 & 4 & 5 & 6 & 7 & 8 & 9 \\
\cline { 2 - 8 }
\end{tabular}

Figure 5. Example of pairwise comparison questions for the evaluation of the SWOT categories.

With reference to strengths, which of the two factors (i.e., sub-criteria) do you think is more important? And to what extent?

\begin{tabular}{l} 
Accessibility \\
\cline { 2 - 8 }
\end{tabular}

Figure 6. Example of pairwise comparison questions for the evaluation of the SWOT factors.

Subsequently, it was necessary to fill in the pairwise comparison questions for alternatives evaluation. In this case, being a specific technical issue, we submitted the questionnaire to the above-mentioned three experts in the field of history of architecture, restoration, and structural analysis, and economic valuation. They evaluated the farmhouses with respect to each selected factor (sub-criterion) and evaluated each factor with respect to SWOT categories (criteria). It worth noting that as far as Strengths and Opportunities are considered, the preference for an alternative means that the alternative is able to maximize the S/O elements, while as far as the Weakness and Threats elements are considered, the preference for an alternative indicates the alternative is able to minimize the W/T elements. As an example, Figures 7 and 8 report two of the questions administered to the panel of experts.

With reference to maximization of accessibility potential, which of the two farmhouses do you think is preferable? And to what extent?

Mandria \begin{tabular}{|l|l|l|l|l|l|l|l|l|l|l|l|l|l|l|l|l|}
9 & 8 & 7 & 6 & 5 & 4 & 3 & 2 & 1 & 2 & 3 & 4 & 5 & 6 & 7 & 8 & 9 \\
\hline
\end{tabular}

Figure 7. Example of pairwise comparison questions for the evaluation of the alternatives with respect to sub-criteria "accessibility".

With reference to the minimization of the threats related to the relationship with the context, which of the two farmhouses do you think is preferable? And to what extent?

\begin{tabular}{|l|l|l|l|l|l|l|l|l|l|l|l|l|l|l|l|l|l|} 
Lavanderia & 9 & 8 & 7 & 6 & 5 & 4 & 3 & 2 & 1 & 2 & 3 & 4 & 5 & 6 & 7 & 8 & 9 \\
Gozzani
\end{tabular}

Figure 8. Example of pairwise comparison questions for the evaluation of the alternatives with respect to sub-criteria "relationship with the context".

Finally, in the third phase, once all the pairwise comparison matrices were replied, we calculated the priorities of the alternatives and multiplied the local weights of each farmhouse by the weights of the SWOT categories and factors previously defined, and obtained the final ranking (see Section 4).

\section{Results and discussion}

As aforementioned, we organized a focus group to validate the hierarchy and the weights by dynamic discussion [61-63]. During the brainstorming, experts processed data and contributed to discussion according to their expertise, and a moderator helped discussion among experts and favored the process of reaching consensus on the final set of weights. We obtained the final set of weights by calculating the geometrical mean of experts' judgments $[64,65]$. In detail, local priorities of objects are 
derived according to the eigenvalue approach to pairwise comparisons and then aggregated within the hierarchy in order to derive global priorities. We implemented the weighted geometric mean aggregation method in the computation of the global priorities as it reflects the preference information contained in local pairwise comparison matrices of alternatives properly [66]. In order to obtain the priority vectors and the final ranking, we implemented the A'WOT model in the Super Decision software. The overall set of weights of criteria and sub-criteria are displayed in Table 1.

Table 1. Criteria and sub-criteria priority vector.

\begin{tabular}{cccc}
\hline Criteria & Sub-Criteria & Priority of Criteria & Priority of Sub-Criteria \\
\hline \multirow{2}{*}{ Strengths } & S1-Accessibility & & 0.083 \\
& S2-State of conservation & 0.386 & 0.121 \\
& S3-Historical/cultural value & & 0.796 \\
\hline \multirow{3}{*}{ Weaknesses } & W1-Ownership & & 0.088 \\
& W2-O\&M costs & 0.034 & 0.243 \\
Opportunities & W3-Current use & & 0.669 \\
& O1-Flexibility & 0.479 & 0.149 \\
& O2-Quality of the context & & 0.785 \\
& O3-Network infrastructures & & 0.066 \\
\hline \multirow{2}{*}{ Threats } & T1-Relationship with the context & 0.100 & 0.279 \\
& T2-Regulatory risks & & 0.072 \\
& T3Budget constraints & & 0.649 \\
\hline
\end{tabular}

According to criteria priorities displayed in the third column of Table 1, Opportunities play a major role (i.e., 0.479) in the successful implementation of valorization strategies, whereas Weaknesses are ranked as fourth (i.e., 0.034). This result is rather intuitive with respect to asset valorization processes, in which the asset potential resides mostly in Opportunities, which counterbalance the negative impact of asset's Weaknesses on strategy implementation. As far as sub-criteria priorities are concerned (fourth column of Table 1), historical/cultural value has the highest priority with respect to strengths (i.e., 0.785), followed by state of conservation (i.e., 0.121) and by accessibility (i.e., 0.083), whose impact is negligible with respect to other factors. As far as Weaknesses are concerned current use has the highest priority (i.e., 0.669 ), whereas the quality of the context is the most important opportunity factor (i.e., 0.785$)$ and the connection to network infrastructures is the least important (0.066). As expected, experts considered budget constraints as the most crucial Threats (i.e., 0.649) and, although it might appear counterintuitive, regulatory risks are ranked as third (i.e., 0.072). It is worth noting that the above priorities represent the relative importance of SWOT factors with respect to the parent node SWOT category. Therefore, although regulatory risks are ranked as last, this does not imply that they are not worth considering in absolute terms, being identified as a Threat in the SWOT analysis.

Finally, Table 2 illustrates alternatives' priority vectors with respect to each sub-criterion as well as ducal farmhouses' final ranking.

According to results, Cascina Lavanderia has the highest potential in the successful implementation of asset valorization strategies. This is mainly because the asset is not currently in use, thus easing any potential intervention, and to the quality of the surrounding context. In fact, it is very close to the park and its favorable location is of paramount importance in the successful design and development of a touristic circuit connecting the four ducal farmhouses in a unitary management perspective. The remaining farmhouses reveal the same potential, with a small preference for Cascina Lamandria, which is ranked as second, due to its good state of conservation. By contrast, Cascina Gozzano is ranked as fourth due to both its state of abandonment and distance from the Castle.

The Lavanderia farmhouse has a great potential in creating a synergy with the park system due to its favorable location and its original reason for construction, as it was built to be of service to Aglié Castle. Although it fell into neglect, its relatively small size (approximately 1400 square meters) 
increases the potential for timely maintenance and refurbishment of the structures, as well as the renovation of the roads connecting it to the park. The classification of the asset state of conservation and the identification of pathologies and degradation represent a crucial phase in the knowledge process and they are preliminary operations to establish the urgency of restoration works, defining the works to be undertaken in a specific site and their progressive order of intervention (Figure 9).

Table 2. Alternatives priority vector and final ranking.

\begin{tabular}{ccccc}
\hline \multirow{2}{*}{ Sub-Criteria } & Lavanderia & Alternatives Priority Vector & \\
& Lamandria & Gozzano & Ortovalle \\
\hline Accessibility & 0.369 & 0.434 & 0.062 & 0.135 \\
State of conservation & 0.066 & 0.571 & 0.060 & 0.303 \\
Historical/cultural value & 0.250 & 0.250 & 0.250 & 0.250 \\
Ownership & 0.406 & 0.068 & 0.476 & 0.050 \\
O\&M costs & 0.051 & 0.104 & 0.422 & 0.422 \\
Current use & 0.446 & 0.065 & 0.446 & 0.043 \\
Flexibility & 0.410 & 0.072 & 0.446 & 0.071 \\
Quality of the context & 0.483 & 0.288 & 0.076 & 0.153 \\
Network infrastructures & 0.522 & 0.182 & 0.137 & 0.159 \\
Relationship with the context & 0.198 & 0.069 & 0.507 & 0.225 \\
Regulatory risks & 0.250 & 0.250 & 0.250 & 0.250 \\
Budget constraints & 0.152 & 0.068 & 0.390 & 0.390 \\
\hline Overall Normal Priority & 0.348 & 0.248 & 0.203 & 0.201 \\
Overall Ideal Priority & 1.000 & 0.710 & 0.583 & 0.578 \\
\hline
\end{tabular}

The main objective is to recover the interconnections of this system to the reality of the Castle and the Park and to establish a unique well-coordinated management strategy.

From this preliminary analysis, it emerged the scenario hypothesis a, in which territorial, social and cultural peculiarities are the most suitable to the characteristics of the asset under investigation, to the detriment of the scenario hypothesis whose characteristics do not fully respond to its valorization needs.

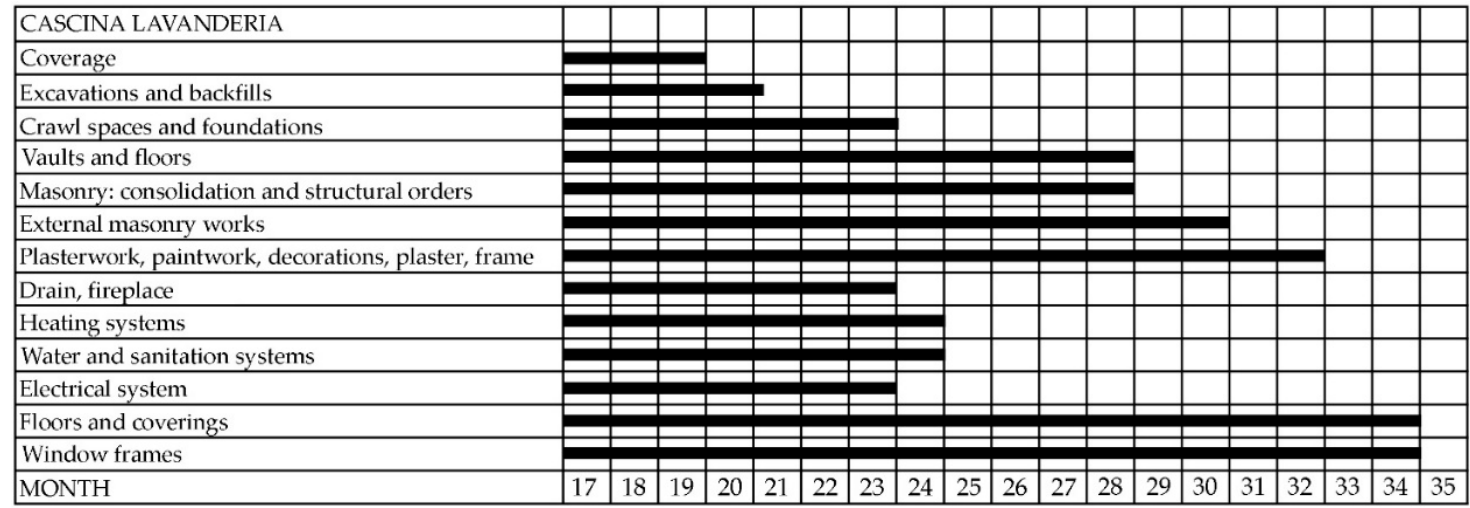

Figure 9. Gantt chart for the intervention works of the Lavanderia farmhouse.

\section{Conclusions}

The design of efficient strategies of cultural heritage assets valorization is a complex process, which requires a profound knowledge of its peculiarities and its identity through history and involves multiple decision variables, actors and stakeholders whose objectives are often conflicting and competing $[67,68]$. Enhancement of cultural heritage consists of giving forms and norms to those activities, which aim at both promoting its knowledge, use and public enjoyment and fostering conservation and restoration works. There is often a dichotomy between the economic and socio-cultural perspectives in defending human values and historical testimonies, which contribute to creating a cultural identity 
through centuries. Due to a lack of financial resources, it is fundamental to improve capacities for the sustainable use of cultural heritage by conserving, protecting, promoting and developing both natural and cultural heritage assets. Indeed, it is generally agreed in literature that sustainable development is a multi-dimensional concept and its evaluation is an interdisciplinary process, which involves cultural, social, environmental and economic disciplines, to show the impact of investment and allocation decisions on common resources. Integrated frameworks are thus necessary to cope with these issues and to support the decision-making processes [20,69]. In this respect, we provided a multi-criteria decision aiding approach for ranking valorization strategies of cultural heritage assets aimed at promoting their restoration and conservation, as well as at creating cultural and economic benefits by focusing on the ducal farmhouses of Aglié Castle estate in the Piedmont region, listed in the UNESCO World Heritage Sites in 1997. We ranked the assets according to their potential in implementing successful valorization strategies. In order to be effective, these strategies should combine, on the one hand, efficient re-use of the above-mentioned buildings (currently in state of abandonment and partially or totally collapsed) and restoration of the original functions they were designed for, with the enhancement of existing synergies between them and the creation of new opportunities for their interconnections with cultural tourism circuits, on the other.

In order to provide guidelines to support the policymaker, it is of paramount importance to structure the analysis into sequential phases. In this respect, we firstly analyzed data relating to the real estate assets under investigation, with the aim of segmenting them for types of feasible interventions. Secondly, we developed the masterplan of the operation of valorization. We then implemented feasibility studies of individual assets in collaboration with the panel of experts to support the policymaker in the implementation phase of valorization actions.

The meta-design phase is de facto a fundamental preliminary step in the design of a future final project meant to the valorization of the farmhouses complex: it consists in constructing a structured mental scheme to clarify the needs that emerged in the preliminary study phase and provide guidelines for valorization strategies implementation. Contribution by different disciplines and technical competency are necessary in order to define the best project proposals to be developed within the preliminary planning stage and designing the final project. Many aspects that interact need to be carefully evaluated in order to obtain a sustainable proposal for compatible re-functionalization and re-use of this set of farmhouses.

According to our analysis, the main aspects to investigate are:

- architectural features and priority ranking of action proposals,

- environmental and landscape issues or road and infrastructure characteristics,

- management and economic/financial outcomes,

- social concerns.

The main objective in the conceptualization of the interventions designed to the restoration and valorization of the Agliè ducal farmhouses is to re-set in place synergies and interconnections between the farmhouses, the city center, and the Castle. In this respect, the determinant of the valorization process identified through our analysis is the inclusion in the Agliè estate of cultural activities, accommodation facilities and the establishment of biodynamic agriculture and organic farming experimental centers.

Cultural activities are key drivers in the valorization process as they add value to memory and testimony of cultural and historical traditions and enhance the knowledge of the historical phases, which have characterized the estate from construction. The development of accommodation facilities is necessary in order to attract and welcome to the farms' tourists (e.g., cultural tourists) from the town and the Castle to the farm: tourists coming to the Castle are currently at 20,000 per year, with a trend destined to grow. Our findings reveal that agriculture and hospitality could be the keystones of the restoration, conservation and financial recovery process involving these assets. 
Based on our results, activities and functions with the highest potential in the implementation of successful management strategies relative to each farmhouse are listed below.

- Cascina Lavanderia: construction of hiking trails, accommodation, and reception facilities, aimed at acting as a filter between activities in the castle -park system and the other farmhouses. This is mainly due to its location directly connected to the park system,

- Cascina Mandria: construction of a center for experimentation in agriculture and horse-riding facilities,

- Cascina Ortovalle: construction of, an experimental/educational center for the growing of vegetables and recovery of its original vocation,

- Cascina Gozzani: construction of an agricultural production center and a cultural center to develop knowledge of Guido Gozzano's life and poetry.

Author Contributions: Conceptualization, M.B., C.D. and A.M.; methodology, M.B., C.D. and A.M.; formal analysis, M.B., C.D. and A.M.; investigation, M.B., C.D. and A.M.; data curation, M.B., C.D. and A.M.; writing M.B., C.D. and A.M. All authors have read and agreed to the published version of the manuscript.

Acknowledgments: Part of the research presented in this paper was carried out within the specialization thesis "Il sistema delle cascine ducali ad Agliè. Dallo studio di fattibilità strategica ad una nuova proposta di valorizzazione" by Alessia Marello, Postgraduate School of Beni Architettonici e del Paesaggio of Politecnico di Torino. Authors are grateful to Professor Monica Naretto for her contribution to the historical archive search and the analysis of the historical issues this study bases on.

Conflicts of Interest: The authors declare no conflict of interest. 


\section{Appendix A}

Table A1. SWOT matrix for the Lavanderia farmhouse.

\begin{tabular}{|c|c|c|c|}
\hline \multicolumn{2}{|r|}{ Strengths } & \multicolumn{2}{|r|}{ Weaknesses } \\
\hline S1 Accessibility & $\begin{array}{l}\text { - } \quad \text { Connection with Park and San Giorgio's street; } \\
\text { - } \quad \text { Accessibility by car or by foot; } \\
\text { Inserted in the network of the farmhouses linked to } \\
\text { the Castle; } \\
\text { - } \quad \text { Presence of farm-roads within the area; } \\
\text { - } \quad \begin{array}{l}\text { Presence of gravel floor driveways with good walkability } \\
\text { and paths connecting to Park system. }\end{array}\end{array}$ & W1 Current use & $\begin{array}{l}\text { - Lack of current function due to the } \\
\text { impossibility of using the } \\
\text { internal spaces; } \\
\text { Large land belonging to farmhouse } \\
\text { bounded by wall, used by storage of } \\
\text { wood and shrubs. }\end{array}$ \\
\hline S2 State of conservation & $\begin{array}{l}\text { Presence of temporary works limiting the spread } \\
\text { of damage. }\end{array}$ & W2 Ownership & $\begin{array}{l}\text { - State property not given in concession } \\
\text { to private; }\end{array}$ \\
\hline S3 Historical/cultural value & $\begin{array}{l}\text { - Presence in several historical maps with the name of } \\
\text { "Cascina del Parco" cause of its position close to } \\
\text { the Castle; } \\
\text { - The building is also referred as "Potagé"; } \\
\text { - Presence in a document concerning the perspective } \\
\text { drawing of the farmhouse with the name of "Cassina } \\
\text { Vecchia"; } \\
\text { - Presence in the Municipal cadastral map of Agliè, 1754, } \\
\text { Giacomo Schiera; } \\
\text { - Presence in the planimetric survey of the Park of the } \\
\text { Aglié Castle, second half of the 19th century; } \\
\text { Presence in the planimetric drawing by Geom. } \\
\text { Vagina. 1850; } \\
\text { - Presence in the planimetric drawing of Castle, garden, } \\
\text { Park and external areas, second half of the 19th century; } \\
\text { Presence in the drawings of the territories of the Park } \\
\text { farmhouses with the name "Cascina Allea" or "Valle". }\end{array}$ & $\begin{array}{l}\text { W3 Operation and } \\
\text { Maintenance costs }\end{array}$ & $\begin{array}{l}\text { Large floor area, park and garden, } \\
\text { which require high operation and } \\
\text { maintenance costs. }\end{array}$ \\
\hline
\end{tabular}


Table A1. Cont.

\section{Opportunities}

Threats

- The dimensions of the building, which are not excessive allow for adaptations and transformations;

- Most of the rooms on ground floor and first floor have vaults and therefore they are not subject to invasive structural changes; floor and they are subject to recovery and conservation; Many rooms are characterized by sail vaults;

T1 Relationship with the context Ground floor hosts a series of interconnecting rooms;

The attic is composed of two types of structures: structure of beams and wood for the upper floors and brick vaults covering the ground floor environments.
Presence of infesting vegetation to take over (shrubs, trees);

- Project of a Biogest approved in 2001;

Arboreal species adjacent to the fronts

of the building obstruct the view, prevent arrival of light, etc.

- $\quad$ Actual use of space belonging to

farmhouse as storage of waste materials.
- $\quad$ Context composed of agricultural fields that are currently in use,

- $\quad$ According to the Municipal Plan, the Cascina is part of

O2 Quality of the context area VP 16 (previously area F2) - Green areas of value The Municipal Plan includes the area in the category of material goods that have generated the current shape of territory, as they constitute historical evidence of the production activity.
T2 Regulatory risks

The presence of the historical constrain ex Lege 1089/39 might affect the business plan or the property use.
The agricultural properties of the context are approximately in $5960 \mathrm{~m} 2$;

O3 Network

infrastructure
Direct connection to the Park of Ducal Castle;

- $\quad$ Presence of a water canal next to the farmhouse;

- Creation of the linking to other farmhouses, especially to the Mandria building.
- The poor state of conservation and the large surface could make difficult to find financial resources and potential investors

- Absence of interest in conservation and enhancement. 


\section{References and Note}

1. Ball, R. Developers, regeneration and sustainability issues in the reuse of vacant industrial buildings. Build. Res. Inf. 1999, 27, 140-148. [CrossRef]

2. Langston, C.; Wong, F.K.; Hui, E.C.; Shen, L.-Y. Strategic assessment of building adaptive reuse opportunities in Hong Kong. Build. Environ. 2008, 43, 1709-1718. [CrossRef]

3. Bullen, P.A.; Love, P.E. Adaptive reuse of heritage buildings. Struct. Surv. 2011, 29, 411-421. [CrossRef]

4. Plevoets, B.; Van Cleempoel, K. Adaptive reuse as a strategy towards conservation of cul-tural heritage: A literature review. WIT Trans. Built Environ. 2011, 118, 155-164.

5. Mısırlısoy, D.; Günçe, K. Adaptive reuse strategies for heritage buildings: A holistic approach. Sustain. Cities Soc. 2016, 26, 91-98. [CrossRef]

6. Dolores, L.; Macchiaroli, M.; De Mare, G. Sponsorship for the Sustainability of Historical-Architectural Heritage: Application of a Model's Original Test Finalized to Maximize the Profitability of Private Investors. Sustainability 2017, 9, 1750. [CrossRef]

7. Forte, C.; De Rossi, B. Principi di Economia ed Estimo; Etas: Milano, Italy, 1974.

8. Mazzanti, M. Cultural heritage as multi-dimensional, multi-value and multi-attribute economic good: Toward a new framework for economic analysis and valuation. J. Socio-Economic. 2002, 31, 529-558. [CrossRef]

9. Pearce, D.W.; Turner, R.K. Economics of Natural Resources and the Environment; Johns Hopkins University Press: Baltimore, MD, USA, 1990.

10. Louviere, J.J.; Hensher, D.A.; Swaitt, J.D. Stated Choice Methods. Analysis and Application; Cambridge University Press: Cambridge, UK, 2000.

11. Voke, M.; Fairley, I.; Willis, M.; Masters, I. Economic evaluation of the recreational value of the coastal environment in a marine renewables deployment area. Ocean Coast. Manag. 2013, 78, 77-87. [CrossRef]

12. Bedate, A.; Herrero, L.C.; Sanz, J. Ángel Economic valuation of the cultural heritage: Application to four case studies in Spain. J. Cult. Heritage 2004, 5, 101-111. [CrossRef]

13. Báez, A.; Herrero, L.C.; Prieto, L.C.H. Using contingent valuation and cost-benefit analysis to design a policy for restoring cultural heritage. J. Cult. Heritage 2012, 13, 235-245. [CrossRef]

14. Wright, W.C.; Eppink, F.V. Drivers of heritage value: A meta-analysis of monetary valuation studies of cultural heritage. Ecol. Econ. 2016, 130, 277-284. [CrossRef]

15. Kee, T. Sustainable adaptive reuse - economic impact of cultural heritage. J. Cult. Heritage Manag. Sustain. Dev. 2019, 9, 165-183. [CrossRef]

16. Roy, B.; Bouyssou, D. Aide Multicritere a la Decision: Methodes et Cas; Economica: Paris, France, 1993.

17. Ferretti, V.; Bottero, M.; Mondini, G. Decision making and cultural heritage: An application of the Multi-Attribute Value Theory for the reuse of historical buildings. J. Cult. Heritage 2014, 15, 644-655. [CrossRef]

18. Nesticò, A.; Morano, P.; Sica, F. A model to support the public administration decisions for the investments selection on historic buildings. J. Cult. Heritage 2018, 33, 201-207. [CrossRef]

19. Bottero, M.; D'Alpaos, C.; Oppio, A. Multicriteria Evaluation of Urban Regeneration Processes: An Application of PROMETHEE Method in Northern Italy. Adv. Oper. Res. 2018, 2018, 1-12. [CrossRef]

20. Bottero, M.; D'Alpaos, C.; Oppio, A. Ranking of Adaptive Reuse Strategies for Abandoned Industrial Heritage in Vulnerable Contexts: A Multiple Criteria Decision Aiding Approach. Sustainability 2019, 11, 785. [CrossRef]

21. Saaty, T.L. The Analytic Hierarchy Process: Planning, Priority Setting, Resource Allocation; McGraw-Hill: New York, NY, USA, 1980.

22. Wheelen, T.L.; Hunger, J.D. Strategic Management and Business Policy, 5th ed.; Addison Wesley: Reading, MA, USA, 1995.

23. Hill, T.; Westbrook, R. SWOT analysis: It's Time for a Product Recall. Long Range Plan. 1997, 30, 46-52. [CrossRef]

24. Kajanus, M. A model for creating innovative strategies for an enterprise and its application to a rural enterprise. Manag. Decis. 2000, 38, 711-722. [CrossRef]

25. Kajanus, M.; Kangas, J.; Kurttila, M. The use of value focused thinking and the A'WOT hybrid method in tourism management. Tour. Manag. 2004, 25, 499-506. [CrossRef]

26. Falcone, P.M.; Tani, A.; Tartiu, V.E.; Imbriani, C. Towards a sustainable forest-based bioeconomy in Italy: Findings from a SWOT analysis. For. Policy Econ. 2020, 110, 101910. [CrossRef] 
27. Kamran, M.; Fazal, M.R.; Mudassar, M. Towards empowerment of the renewable energy sector in Pakistan for sustainable energy evolution: SWOT analysis. Renew. Energy 2020, 146, 543-558. [CrossRef]

28. Kurttila, M.; Pesonen, M.; Kangas, J.; Kajanus, M. Utilizing the analytic hierarchy process (AHP) in SWOT analysis-a hybrid method and its application to a forest-certification case. For. Policy Econ. 2000, 1, 41-52. [CrossRef]

29. Pesonen, M.; Kurttila, M.; Kangas, J.; Kajanus, M.; Heinonen, P. Assessing the priorities using A'WOT among resource management strategies at the Finnish Forest and Park Service. For. Sci. 2001, 47, 534-541.

30. Kangas, J.; Kangas, A.; Leskinen, P.; Pykäläinen, J. MCDM methods in strategic planning of forestry on state-owned lands in Finland: Applications and experiences. J. Multi-Criteria Decis. Anal. 2001, 10, 257-271. [CrossRef]

31. Saaty, T.L. Fundamentals of Decision Making and Priority Theory with the Analytic Hierarchy Process, 1st ed.; RWS Publications: Pittsburgh, PA, USA, 2000.

32. Kajanus, M.; Leskinen, P.; Kurttila, M.; Kangas, J. Making use of MCDS methods in SWOT analysis-Lessons learnt in strategic natural resources management. For. Policy Econ. 2012, 20, 1-9. [CrossRef]

33. Vacik, H.; Kurttila, M.; Hujala, T.; Khadka, C.; Haara, A.; Pykäläinen, J.; Honkakoski, P.; Wolfslehner, B.; Tikkanen, J. Evaluating collaborative planning methods supporting programme-based planning in natural resource management. J. Environ. Manag. 2014, 144, 304-315. [CrossRef]

34. Moharramnejad, N.; Rahnamai, M.-T.; Dorbeiki, M. Application of A'WOT Method in Strategic Management of Sustainable Tourism in a National Park. Environ. Eng. Manag. J. 2017, 16, 471-480.

35. Gallego-Ayala, J.; Juizo, D. Performance evaluation of River Basin Organizations to implement integrated water resources management using composite indexes. Phys. Chem. Earth Parts A/B/C 2012, 50, 205-216. [CrossRef]

36. Podimata, M.V.; Yannopoulos, P.C. Evaluating challenges and priorities of a trans-regional river basin in Greece by using a hybrid SWOT scheme and a stakeholders' competency overview. Int. J. River Basin Manag. 2013, 11, 93-110. [CrossRef]

37. Gallego-Ayala, J.; Juizo, D. Integrating Stakeholders' Preferences into Water Resources Management Planning in the Incomati River Basin. Water Resour. Manag. 2014, 28, 527-540. [CrossRef]

38. Chitsaz, N.; Azarnivand, A. Water Scarcity Management in Arid Regions Based on an Extended Multiple Criteria Technique. Water Resour. Res. 2017, 31, 233-250. [CrossRef]

39. Kişi, N. A Strategic Approach to Sustainable Tourism Development Using the A'WOT Hybrid Method: A Case Study of Zonguldak, Turkey. Sustainability 2019, 11, 964. [CrossRef]

40. Canto-Perello, J.; Curiel-Esparza, J.; Calvo, V. Strategic decision support system for utility tunnel's planning applying A'WOT method. Tunn. Undergr. Space Technol. 2016, 55, 146-152. [CrossRef]

41. Pellegrino, D.; Schirpke, U.; Marino, D. How to support the effective management of Natura 2000 sites? J. Environ. Plann. Man. 2017, 60, 383-398. [CrossRef]

42. Kittiyankajon, M.; Chetchotsak, D.; Ruangchoengchum, P. Group decision technique for multiple criteria evaluation problems: The preferential difference and rank approach through data envelopment analysis. IJBIR 2019, 18, 410-427. [CrossRef]

43. Bottero, M.; Comino, E.; Dell'Anna, F.; Dominici, L.; Rosso, M. Strategic Assessment and Economic Evaluation: The Case Study of Yanzhou Island (China). Sustainability 2019, 11, 1076. [CrossRef]

44. Roberti, F.; Oberegger, U.F.; Lucchi, E.; Gasparella, A. Energy retrofit and conservation of built heritage using multi-objective optimization: Demonstration on a medieval building. Build. Simul. 2015, 2, 189-197.

45. Roberti, F.; Oberegger, U.F.; Lucchi, E.; Troi, A. Energy retrofit and conservation of a historic building using multi-objective optimization and an analytic hierarchy process. Energy Build. 2017, 138, 1-10. [CrossRef]

46. Turskis, Z.; Morkunaite, Z.; Kutut, V. A hybrid multiple criteria evaluation method of ranking of cultural heritage structures for renovation projects. Int. J. Strateg. Prop. Manag. 2017, 21, 318-329. [CrossRef]

47. Bozic, S.; Vujicic, M.; Kennell, J.; Besermenji, S.; Solarevic, M. Sun, sea and shrines: Application of analytic hierarchy process (AHP) to assess the attractiveness of six cultural heritage sites in Phuket: Thailand. Geogr. Pannonica 2018, 22, 121-138. [CrossRef]

48. Keyvanfar, A.; Shafaghat, A.; Mohamad, S.; Abdullahi, M.; Ahmad, H.; Derus, N.M.; Khorami, M. A Sustainable Historic Waterfront Revitalization Decision Support Tool for Attracting Tourists. Sustainability 2018, 10, 215. [CrossRef] 
49. Liu, F.; Zhao, Q.; Yang, Y. An approach to assess the value of industrial heritage based on Dempster-Shafer theory. J. Cult. Heritage 2018, 32, 210-220. [CrossRef]

50. Ma,H.; Li, S.; Chan, C.-S. Analytic Hierarchy Process (AHP)-based assessment of the value of non-World Heritage Tulou: A case study of Pinghe County, Fujian Province. Tour. Manag. Perspect. 2018, 26, 67-77. [CrossRef]

51. Ribera, F.; Nesticò, A.; Cucco, P.; Maselli, G. A multicriteria approach to identify the Highest and Best Use for historical buildings. J. Cult. Heritage 2019, in press. [CrossRef]

52. Iliopoulou-Georgudaki, J.; Theodoropoulos, C.; Konstantinopoulos, P.; Georgoudaki, E. Sustainable tourism development including the enhancement of cultural heritage in the city of Nafpaktos-Western Greece. Int. J. Sustain. Dev. World 2017, 24, 224-235. [CrossRef]

53. Guzman, P.; Roders, A.P.; Colenbrander, B. Impacts of Common Urban Development Factors on Cultural Conservation in World Heritage Cities: An Indicators-Based Analysis. Sustainability 2018, 10, 853. [CrossRef]

54. Dastgerdi, A.S.; De Luca, G. The Riddles of Historic Urban Quarters Inscription on the Unesco World Heritage List. Archnet-IJAR: Int. J. Arch. Res. 2018, 12, 152-163. [CrossRef]

55. Ali, A.G.M.; Elsheikha, A.A.A.; Elbanna, E.M.; Peinado, F.J.M. An approach to conservation and management of Farasan Islands' Heritage sites, Saudi Arabia. Int. J. Conserv. Sci. 2018, 9, 245-256.

56. Lak, A.; Gheitasi, M.; Timothy, D.J. Urban regeneration through heritage tourism: Cultural policies and strategic management. J. Tour. Cult. Chang. 2019, in press. [CrossRef]

57. Vinardi, M.G. Scavalcò lo steccato e vide che la natura era tutto un giardino. In Il risveglio del giardino: Dall'hortus al paesaggio, studi, esperienze, confronti; Cornaglia, P., Giusti, M.A., Eds.; Pacini Fazzi: Lucca, Italy, 2015; p. 83.

58. Antoniono, R. Il castello d'Agliè: Una residenza aulica e un territorio. Master's Thesis, Politecnico di Torino, Turin, Italy, 1996; p. 149.

59. Comoli, V.; Vanelli, A. Le residenze sabaude: Dizionario dei personaggi; Roggero, C., Poletto, S., Eds.; Regione Piemonte: Accolade, Torino, 2008; p. 44.

60. Colla, G.B. Tipo regolare del Parco, Castello, Giardini e Valle e limiti in coerenza di codesto Castello spettante a S.A.R. il Sig. Duca del Chiablese, Agliè, lì 25 febbraio 1975, Paper drawing, Archivio Antico, Agliè.

61. Banzato, D.; Canesi, R.; D'Alpaos, C. Biogas and biomethane technologies: An AHP model to support the policy maker in incentive design in Italy. In Smart and Sustainable Planning for Cities and Regions. SSPCR 2017; Green Energy and Technology; Bisello, A., Vettorato, D., Laconte, P., Costa, S., Eds.; Springer: Cham, Switzerland, 2018; pp. 319-331. [CrossRef]

62. D'Alpaos, C.; Bragolusi, P. Multicriteria prioritization of policy instruments in buildings energy retrofit. Valori e Valutazioni 2018, 21, 15-25.

63. D'Alpaos, C.; Bragolusi, P. Prioritization of Energy Retrofit Strategies in Public Housing: An AHP Model. In New Metropolitan Perspectives. ISHT 2018; Smart Innovation, Systems and Technologies, vol 101; Calabrò, F., Della Spina, L., Bevilacqua, C., Eds.; Springer: Cham, Switzerland, 2019; pp. 534-541. [CrossRef]

64. Grošelj, P.; Stirn, L.Z. Acceptable consistency of aggregated comparison matrices in analytic hierarchy process. Eur. J. Oper. Res. 2012, 223, 417-420. [CrossRef]

65. Dong, Q.; Saaty, T.L. An analytic hierarchy process model of group consensus. J. Syst. Sci. Syst. Eng. 2014, 23, 362-374. [CrossRef]

66. Krejčí, J.; Stoklasa, J. Aggregation in the analytic hierarchy process: Why weighted geometric mean should be used instead of weighted arithmetic mean. Expert Syst. Appl. 2018, 114, 97-106. [CrossRef]

67. Della Spina, L. Scenarios for a Sustainable Valorisation of Cultural Landscape as Driver of Local Development In New Metropolitan Perspectives. ISHT 2018; Smart Innovation, Systems and Technologies, vol. 101; Calabrò, F., Della Spina, L., Bevilacqua, C., Eds.; Springer: Cham, Switzerland, 2019; pp. 113-122. [CrossRef]

68. Della Spina, L. Historical Cultural Heritage: Decision Making Process and Reuse Scenarios for the Enhancement of Historic Buildings. Development. In New Metropolitan Perspectives. ISHT 2018; Smart Innovation, Systems and Technologies, vol. 101; Calabrò, F., Della Spina, L., Bevilacqua, C., Eds.; Springer: Cham, Switzerland, 2019; pp. 442-453. [CrossRef]

69. Bottero, M.; Caprioli, C.; Cotella, G.; Santangelo, M. Sustainable Cities: A Reflection on Potentialities and Limits based on Existing Eco-Districts in Europe. Sustainability 2019, 11, 5794. [CrossRef]

(C) 2020 by the authors. Licensee MDPI, Basel, Switzerland. This article is an open access article distributed under the terms and conditions of the Creative Commons Attribution (CC BY) license (http://creativecommons.org/licenses/by/4.0/). 